\title{
Related Device Identifier
}

National Cancer Institute

\section{Source}

National Cancer Institute. Related Device Identifier. NCI Thesaurus. Code C117710.

A character or string that identifies and represents a related device. 